\title{
Influence of MDRI methylation on the curative effect of interventional embolism chemotherapy for cervical cancer
}

This article was published in the following Dove Press journal:

Therapeutics and Clinical Risk Management

15 February 2016

Number of times this article has been viewed

\author{
Zhi Huangl,* \\ Shuai Zhang',* \\ Yaping Shen' \\ Weixin Liu' \\ Jipu Long' \\ Shi Zhou'
}

'Department of Interventional Radiology, The Affiliated Baiyun Hospital of Guizhou Medical University, Guizhou Medical University, Guiyang, People's Republic of China; ${ }^{2}$ Department of Interventional Radiology, Cancer Hospital of Guizhou Medical University, Guiyang, People's Republic of China

*These authors contributed equally to this work
Correspondence: Shi Zhou Department of Interventional Radiology, The Affiliated Baiyun Hospital of Guizhou Medical University, Guizhou Medical University, 28 Guiyang City Medical Street, Guiyang 550002, People's Republic of China Email zhousgz@yeah.net
Background: Multi-drug resistance (MDR) is the main cause of tumor failure to chemotherapy. This study aims to explore the influence of MDR1 methylation on curative effect of interventional embolism chemotherapy for cervical cancer.

Methods: Sixty-seven patients with cervical cancer receiving embolism chemotherapy were selected, and 45 normal cervical tissues were included as a control. Immunohistochemistry was used to detect the level of P-glycoprotein (P-gp) in cervical cancer, and to make an analysis compared with normal tissues. The methylation status of the MDRI gene promoter region 16 $\mathrm{CpG}$ units was analyzed by using kilobase-specific cracking and matrix-assisted laser desorption ionization time of flight mass spectrometry.

Results: The results indicated that the positive expression rates of P-gp were $0 \%(0 / 45)$ in normal cervical tissue, and $61.19 \%(41 / 67)$ and $77.61 \%(52 / 67)$ before and after interventional embolism chemotherapy in cervical cancer tissues, respectively. There were significant differences compared with normal cervical tissues $\left(\chi^{2}=4.2523,0.0392\right)$. The positive expression rate of P-gp before chemotherapy was negatively correlated with efficacy of chemotherapy $(r=-0.340$, $P=0.005)$. Methylation rate of $13 \mathrm{CpG}$ units in normal tissues was significantly greater than cervical tissues $(P<0.05)$. In cervical cancer tissue, methylation rate of six $\mathrm{CpG}$ units before interventional embolism chemotherapy was higher than after chemotherapy, but that of one $\mathrm{CpG}$ unit was lower than after chemotherapy $(P<0.05)$. The methylation rate of one $\mathrm{CpG}$ unit with effective chemotherapy before chemotherapy was significantly higher than ineffective chemotherapy $(P<0.05)$, and the other CpG units were similar $(P>0.05)$.

Conclusion: P-gp expression level coded by MDR1, methylation status of partial MDR1 gene promoter regions $\mathrm{CpG}$ island, is closely related to the efficacy of interventional embolism chemotherapy for cervical cancer before the operation.

Keywords: cervical cancer, interventional embolism chemotherapy, $M D R 1$ gene, methylation, immunohistochemistry

\section{Introduction}

Cervical cancer is one of the most common gynecologic malignant tumors, and the morbidity is secondary to breast cancer. According to the statistics, cervical cancer takes up approximately $10 \%$ of gynecologic malignant tumor, with the yearly increasing cases of 471,000 and the yearly death cases of $275,000 .{ }^{1,2}$ Surgery and radiotherapy are the main methods of treatment for cervical cancer. However, although surgical skills, radiotherapy equipment, and technology update in recent decades, the therapeutic effect is not enhanced and the 5-year survival rate is only $70 \%{ }^{1,2}$ Tumor local uncontrol and reoccurrence is the main cause of treatment failure, followed by lymphatic metastasis and metastasis. 
Neoadjuvant chemotherapy is defined as a certain course of chemotherapy that the patients receive before the main treatment method to shrink the tumor volume, improve the operation results, and reduce operative complications, and is especially effective in patients with adenocarcinoma insensitive to radiotherapy. ${ }^{3}$ Cervical cancer is moderately sensitive to chemotherapy, so preoperative chemotherapy can effectively reduce tumor load, control infiltrating vessel carcinoma embolus in parametrium, reduce the radiotherapy burden, increase the operative respectability, and decrease the reoccurrence rate. ${ }^{4}$ Neoadjuvant intra-arterial chemotherapy is the new representative treatment strategy. For this strategy, the radical trachelectomy and lymphadenectomy are done after embolism chemotherapy through the internal iliac artery and uterine artery. Also, the treatment can reserve uterine, fallopian tube, and ovaries, therefore, it is of significance to patients with early cervical cancer who want to preserve fertility. Nevertheless, lots of patients are not sensitive to interventional embolism chemotherapy, so carrying out chemotherapy for such patients will delay the overall treatment and cause unnecessary side effects and increase the financial burden. ${ }^{5}$ Therefore, urgently seeking for indexes predicting chemo-sensitivity provides the guidance for its treatment.

Multi-drug resistance (MDR) is the main cause of tumor failure to chemotherapy. Relevant study showed that P-glycoprotein (P-gp) coded by MDRl gene is a marker of MDR, and the inhibition of its expression can enhance the sensitivity of certain tumor cells to chemotherapy drugs. ${ }^{6,7}$ In this study, immunohistochemistry was used to detect the level of P-gp in cervical cancer before and after interventional embolism chemotherapy, and the methylation status of MDRl gene was analyzed by kilobase-specific cracking and matrix-assisted laser desorption ionization time of flight mass spectrometry, with the intention to explore the influence of MDR1 methylation on the curative effect of preoperative interventional embolism chemotherapy for cervical cancer.

\section{Patients and methods}

\section{General data}

Sixty-seven patients with cervical cancer receiving embolism chemotherapy by pathological confirmation in the Affiliated Baiyun Hospital of Guizhou Medical University from January 2013 to January 2015 were selected and all patients had not previously had radiotherapy and chemotherapy. Additionally, 45 normal cervical tissues by cervical biopsy or excision were selected as controls. This study was approved by the ethics committee of the Affiliated Baiyun Hospital of Guizhou
Medical University, Guiyang, People's Republic of China. The study adhered to the ethics guidelines of the Declaration of Helsinki. All the patients and normal individuals gave their informed, written consent and approved the present study.

\section{Level of P-gp in cervical cancer tissues detected by immunohistochemistry}

Cervical cancer and normal cervical tissues before and after interventional treatment were embedded into paraffin, cut into $5 \mu \mathrm{m}$ slices, and conventional xylene dewaxing and gradient alcohol hydration was performed. Then the tissues were endogenously peroxidase sealed by $3 \%$ hydrogen peroxide solution, distilled water to rinse three times, and citrate buffer boiling repair antigen. The first antibody (mouse antiP-gp monoclonal antibody purchased from Abcam PLC [Cambridge, UK]) was added and put in a humidified box at $4^{\circ} \mathrm{C}$ for staying overnight, washed with Tris-buffered saline for three times, diaminobenzidine developing (DAB Chromogenic Reagent Kit by ZSGB-BIO, Beijing, People's Republic of China), hematoxylin staining for 1 minute, dehydration and transparency, and finally sealed by neutral balsam. The known positive biopsy was regarded as a positive control and phosphate-buffered saline instead of the primary antibody was considered as a control.

\section{Detection of the methylation status of MDRI gene}

\section{The extraction and identification of DNA}

Cervical cancer and normal cervical tissues during 2-3 weeks before and after interventional treatment were taken for DNA extraction by QIAamp DNA Mini Kit (Qiagen NV, Venlo, the Netherlands), strictly according to specification. The house-keeping gene $\beta$-globin (primer sequences: forward: 5'-CAACTTCATCCACGTTCACC-3'; reverse: 5'-GAAGAGCCAAGGACAGGTAC-3') was the internal control for PCR amplification. The PCR-amplified product was confirmed by sequencing as the positive cervical samples of $\beta$-globin DNA (positive control) and sterilized doubledistilled water $\left(\mathrm{ddH}_{2} \mathrm{O}\right)$ was designed as blank control. PCR product was identified by $2 \%$ agarose gel electrophoresis. If the product is obviously seen, the quality of DNA was passed. The DNA concentration and purity was detected by the ultraviolet photometer.

\section{The methylation process: PCR and in vitro transcription}

DNA was processed by hydrosulfite according to kit introduction and then performed with PCR. The EZ DNA 
methylation kit was purchased from the Zymo Research Corporation (Irvine, CA, USA). The reaction system was $3 \mu \mathrm{L}$, including $0.9 \mu \mathrm{L} \mathrm{ddH}_{2} \mathrm{O}, 0.5 \mu \mathrm{L} 10 \times$ PCR buffer $\left(\mathrm{Mg}^{2+}\right), 0.4 \mu \mathrm{L} \mathrm{MgCl}{ }_{2}, 0.1 \mu \mathrm{L} 25 \mathrm{mM}$ dNTP, $1 \mu \mathrm{L}$ primer mix, and $0.1 \mu \mathrm{L} 5 \mathrm{U} / \mu \mathrm{L}$ PCR enzyme. MDR 1 gene sequences of primers: forward: 5'-TTGGAGGTGAGATTAATTT-3'b; reverse: 5'-AAAAAAACCCCTACAATACCCATC-3'c, $\mathrm{b}$ and $\mathrm{c}$ are primers, prefix of primers, that is, each forward primer marks ten base sequence ( $5^{\prime}$-AGGAAGAGAG-3') and each reserve primer marks a $\mathrm{T} 7$ promoter $\left(5^{\prime}\right.$-CAGTAA TACGACTCACTATAGGGAGAAGGCT-3'). The reaction condition was $94^{\circ} \mathrm{C}$ for 4 minutes, $94^{\circ} \mathrm{C}$ for 20 seconds, $56^{\circ} \mathrm{C}$ for 30 seconds, $72^{\circ} \mathrm{C}$ for 1 minute, 45 cycles in total, and last $72^{\circ} \mathrm{C}$ for 3 minutes. After the reaction, $5 \mu \mathrm{L}$ PCR product was taken and added with $2 \mu \mathrm{L}$ shrimp alkaline phosphatase mixture (including $0.3 \mu \mathrm{L}$ shrimp alkaline phosphatase and $1.7 \mu \mathrm{L} \mathrm{ddH_{2 }} \mathrm{O}$ ), centrifuged and incubated at $37^{\circ} \mathrm{C}$ for 20 minutes, then at $85^{\circ} \mathrm{C}$ for 5 minutes for eliminating the free nucleotide in the reaction system. The product $(2 \mu \mathrm{L})$ was put in microwell plate, added with $5 \mu \mathrm{L}$ transcription/RNase A mixture (including $3.15 \mu \mathrm{L}$ RNase-free $\mathrm{ddH}_{2} \mathrm{O}, 0.89 \mu \mathrm{L}$ $5 \times$ Tris $(\mathrm{T})$ and polymerase buffer, $0.24 \mu \mathrm{L}$ T cleavage mix, $0.22 \mu \mathrm{L} 100 \mathrm{mM}$ DL-Dithiothreitol (DTT), $0.44 \mu \mathrm{L}$ T7 RNA and DNA polymerase, and $0.06 \mu \mathrm{L}$ RNase A), sealed, and centrifuged. The product was finally incubated at $37^{\circ} \mathrm{C}$ for 3 hours, and preserved at $4^{\circ} \mathrm{C}$.

\section{Detection of methylation rate}

The methylation status of the MDR 1 gene promoter region of $16 \mathrm{CpG}$ units was analyzed by kilobase-specific cracking and matrix-assisted laser desorption ionization time of flight mass spectrometry. Nanodispenser was used to take $22 \mathrm{~nL}$ lytic reaction liquid to add to matrix chip, and MassARRAY (Sequenom, San Diego, CA, USA) was used to collect mass spectrum. The methylation rate of mass spectrum was analyzed by Epityper 1.0 software.

\section{Evaluation criteria}

\section{Evaluation for chemotherapy curative effect}

The three-dimensional radial line was detected by transvaginal ultrasonography during 2-3 weeks before and after chemotherapy for calculating the volume of tumor, mainly marked by incrassation in parametrium, loss of normal cervical morphology, disappeared sacrum cardinal ligament. Parametric infiltration was calculated according to the unilateral side. In accordance with International Union Against Cancer, criteria of curative effect include complete remission, partial remission, stable disease, and progressive disease. Complete remission and partial remission refer to effective, and stable disease and progressive disease refer to ineffective.

\section{Evaluation for P-gp expression level}

P-gp positive particles showed brownness in the membrane and cytoplasm. Four visual fields were selected under the high-power lens for counting 200 cells. The number of positive cells $<10 \%$ indicated with "-", $10 \%-25 \%$ indicated with " + ", $>25 \%-75 \%$ indicated with " ++ ", and $>75 \%$ indicated with " +++ ". + to +++ refers to the positive expression.

\section{Statistical data analysis}

SPSS 17.0 software was used for data analysis. The enumeration data were expressed as a percentage $(\%)$, the rate of groups was analyzed by $\chi^{2}$ test, and the correlation was by Spearman's rank correlation analysis. The methylation levels between cervical cancer tissue and normal cervical tissue, before and after treatment for cervical cancer tissues were analyzed by the Wilcoxon rank sum test. A value of $P<0.05$ was considered statistically significant.

\section{Results \\ Demographics of patients}

The patients were aged 27-68 years, with the median age of 53 years. According to the cervical cancer clinical staging of International Federation of Gynecology and Obstetrics, the patients were divided into Ib2, IIa, IIb, IIIa, and IIIb stage, which were listed in Table 1. All the patients, 48 patients with squamous carcinoma and 19 patients with adenocarcinoma, were also divided into poorly differentiated, moderately differentiated, and highly differentiated degree (Table 1).

Table I Demographics of the patients involved in this study

\begin{tabular}{ll}
\hline Demographics & Values \\
\hline Age (years), mean (range) & $53(27-68)$ \\
FIGO stage, $n$ & \\
Ib2 & 21 \\
Ila & 16 \\
Ilb & 13 \\
Illa & 10 \\
IIllb & 7 \\
Cancer type, $n$ & \\
Squamous carcinoma & 48 \\
Adenocarcinoma & 19 \\
Differentiated degree, $n$ & \\
Poor & 4 \\
Moderate & 24 \\
High & 39 \\
\hline
\end{tabular}

Abbreviation: FIGO, International Federation of Gynecology and Obstetrics. 

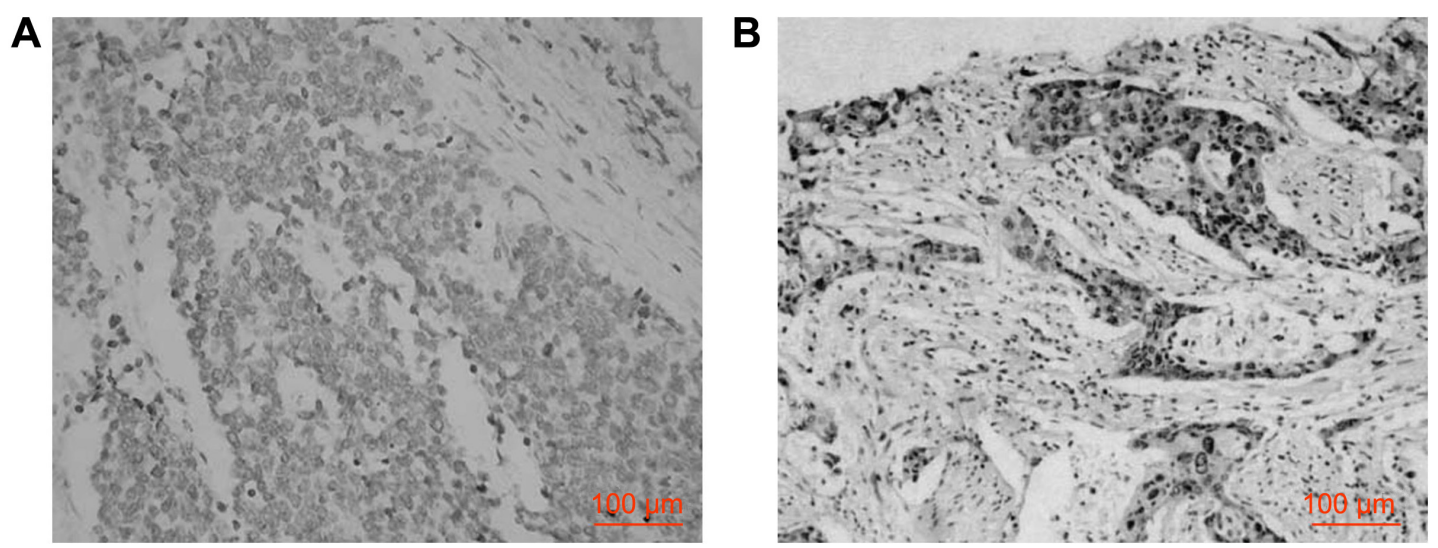

Figure I Expression of P-glycoprotein in normal cervical tissues and cervical cancer tissues.

Notes: (A) Normal cervical tissues; (B) cervical cancer tissue.

\section{The P-gp expression level in normal} tissues and cervical cancer tissues before and after interventional embolism chemotherapy

The positive expression rate of P-gp was $0 \%(0 / 45)$ in the normal cervical tissues, $61.19 \%(41 / 67)$ and $77.61 \%(52 / 67)$ in cervical cancer tissues before and after interventional embolism chemotherapy. The positive expression rate of P-gp after interventional embolism chemotherapy was higher than after interventional embolism chemotherapy $\left(\chi^{2}=4.2523, P=0.0392\right)$. The expression intensity of P-gp after chemotherapy increased in cervical cancer tissues compared with before chemotherapy before $\left(\chi^{2}=17.7301, P=0.0005\right)$ (Figure 1 and Table 2$)$.

\section{Influence of P-gp expression on chemotherapeutic effect before chemotherapy}

The positive expression rate of P-gp before chemotherapy was negatively correlated with chemotherapeutic effect ( $r=-0.340, P=0.005$ ). The positive expression rate of $\mathrm{P}$-gp before chemotherapy in patients with effective chemotherapy was lower than in patients with invalid chemotherapy $\left(\chi^{2}=7.7274, P=0.0054\right)$ (Table 3$)$.

\section{The identification and purification of DNA}

After $\beta$-globin PCR product was performed with $2 \%$ agarose gel electrophoresis, the target fragments appeared at $240 \mathrm{bp}$, as shown in Figure 2. Ultraviolet absorbency degree OD260/ OD280 was $1.8-2.0$, with DNA concentration $>50 \mathrm{ng} / \mu \mathrm{L}$, applicable for PCR amplification.

\section{Methylation status of MDRI in normal tissues and cervical cancer tissues before and after chemotherapy}

Mass spectrum accurately positioned methylation status of each $\mathrm{CpG}$ unit of gene segment. Each sample amplicon in the present study included $16 \mathrm{CpG}$ units, and each $\mathrm{CpG}$ unit included single or multiple $\mathrm{CpG}$ loci, as shown in Table 4. The methylation rate of $13 \mathrm{CpG}$ units (Unit 2-Unit 11 and Unit 14-Unit 16) in normal cervical tissue was higher than cervical cancer tissues $(P<0.05)$. The methylation rate of six $\mathrm{CpG}$ units (Unit 4, Unit 5, Unit 8-Unit 10, Unit 16) was higher in cervical cancer tissue before chemotherapy than after chemotherapy, but the methylation rate of Unit 14 was lower than after chemotherapy $(P<0.05)$ (Figure 3).

Table 2 Comparison of P-gp expression level in normal tissues and cervical cancer tissues before and after interventional embolism chemotherapy

\begin{tabular}{llllllll}
\hline & Tissue & \multicolumn{2}{l}{ P-gp expression level, $\mathbf{n}(\%)$} & & \multirow{2}{*}{$\chi^{2}$} & \multirow{P}{*}{-value } \\
\cline { 2 - 6 } & samples, $\mathbf{n}$ & $\mathbf{( - )}$ & $\mathbf{( + )}$ & $\mathbf{( + + )}$ & $\mathbf{( + + + )}$ & \\
\hline Before chemotherapy & 67 & $26(38.8 I)$ & $24(35.82)$ & $10(14.93)$ & $7(10.45)$ & 17.7301 & 0.0005 \\
After chemotherapy & 67 & $15(22.39)$ & $11(16.42)$ & $25(37.31)$ & $16(23.88)$ & NA & NA \\
\hline
\end{tabular}

Notes: "-" refers to $<10 \%$ positive cells; "+" refers to $10 \%-25 \%$ positive cells; "++" refers to $>25 \%-75 \%$ positive cells; and "+++" refers to $>75 \%$ positive cells.

Abbreviations: NA, not applicable; P-gp, P-glycoprotein. 
Table 3 Correlation between the expression of P-gp before chemotherapy and chemotherapeutic effect

\begin{tabular}{|c|c|c|c|c|c|}
\hline \multirow[t]{2}{*}{ Efficacy } & \multirow[t]{2}{*}{$\begin{array}{l}\text { Tissue } \\
\text { samples, } n\end{array}$} & \multicolumn{2}{|c|}{$\begin{array}{l}\text { P-gp expression } \\
\text { level, } \mathbf{n}(\%)\end{array}$} & \multirow[t]{2}{*}{$\chi^{2}$} & \multirow[t]{2}{*}{$P$-value } \\
\hline & & Negative & Positive & & \\
\hline Effective & 52 & $28(53.85)$ & $24(46.15)$ & 7.7274 & 0.0054 \\
\hline Ineffective & 15 & $2(13.33)$ & $13(86.67)$ & NA & NA \\
\hline
\end{tabular}

Abbreviations: NA, not applicable; P-gp, P-glycoprotein.

\section{Influence of MDR I methylation status on chemosensitivity}

The methylation rate of $\mathrm{CpG}$ _2, 3, and 4 loci before chemotherapy in patients with effective chemotherapy was higher than patients with ineffective chemotherapy, and there was no difference in the methylation rate among the other $\mathrm{CpG}$ loci $(P>0.05)$ (Figure 4).

\section{Discussion}

The $M D R$ gene family includes $M D R 1$ and $M D R 3$, but only $M D R 1$ gene can produce MDR phenomena. MDR1 gene is located in 7q21.1-q21.3 loci on chromosome 7 , including 29 exons and 28 introns and coding drug carrier P-gp. ${ }^{8}$ P-gp, one of the members in the superfamily of ATP-binding cassette transporters, has energy-dependent expanding membrane efflux pumping function, pumps a variety of antitumor drugs out of cells, makes intracellular

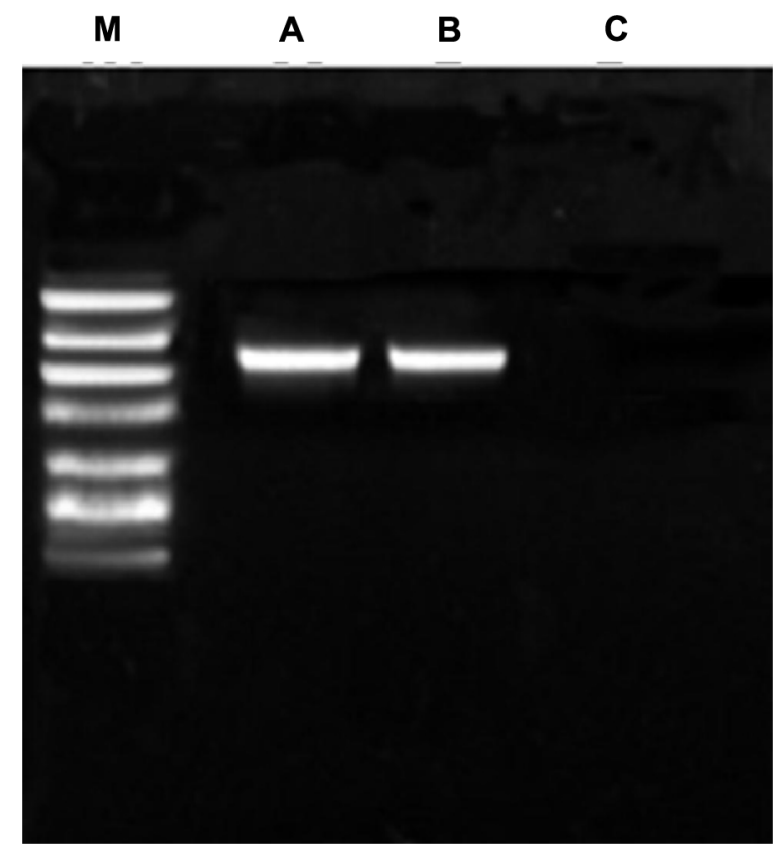

Figure $2 \beta$-Globin PCR product electrophoretogram.

Notes: M, DNA marker; A, sample; B, positive control; C, blank control.

Abbreviation: PCR, polymerase chain reaction.
Table 4 CpG units and the corresponding CpG loci in amplicon

\begin{tabular}{ll}
\hline CpG units & CpG loci \\
\hline Unit I & CPG_2,3,4 \\
Unit 2 & CPG_5 \\
Unit 3 & CPG_6 \\
Unit 4 & CPG_7 \\
Unit 5 & CPG_8 \\
Unit 6 & CPG_9,10 \\
Unit 7 & CPG_11 \\
Unit 8 & CPG_I2,13 \\
Unit 9 & CPG_18 \\
Unit I0 & CPG_19,20 \\
Unit II & CPG_22 \\
Unit I2 & CPG_23 \\
Unit I3 & CPG_24 \\
Unit I4 & CPG_25,26,27 \\
Unit I5 & CPG_28 \\
Unit 16 & CPG_30 \\
\hline
\end{tabular}

chemotherapeutics fall short of effective dose, thus producing drug resistance. ${ }^{9-11}$ MDR produced by the drug efflux function of P-gp-mediated tumor is close to the level of $\mathrm{P}$-gp expression. P-gp is lowly expressed in tumor cells with drug susceptibility and highly expressed in drug-resistant tumor cells. ${ }^{12}$ Scheiner et al ${ }^{13}$ detected the P-gp expression level in 109 patients with acute myeloid leukemia, and the results showed that the expression of $\mathrm{P}$-gp was negatively correlated with the treatment remission rate, hence, it was the poor prognostic factor. Zhu et al ${ }^{14}$ used immunohistochemical method to detect the expression of P-gp in 82 patients with breast cancer and analyzed the relationship between the clinicopathological features and the prognosis of the patients, the results showed that the P-gp expression level was closely associated with the prognosis of patients with breast cancer, the higher the expression level, the lower the survival rate. In the present research, P-gp was not expressed in normal cervical tissues and highly expressed in cervical cancer tissues, and the positive expression rate of $\mathrm{P}$-gp before chemotherapy in patients with effective chemotherapy was lower than in patients with invalid chemotherapy, which was consistent with the results of the previous studies. Additionally, the present study also revealed that the P-gp expression level significantly increased after interventional embolism chemotherapy, indicating chemotherapy could induce the expression of $\mathrm{P}$-gp in cervical cancer tissues and P-gp might be close to secondary resistance.

DNA methylation is a potential biomarker of tumor. Generally, DNA methylation can inhibit the gene expression and the hypo-methylation of the whole genome is one of the most important characteristics of tumor cells. ${ }^{15}$ The 


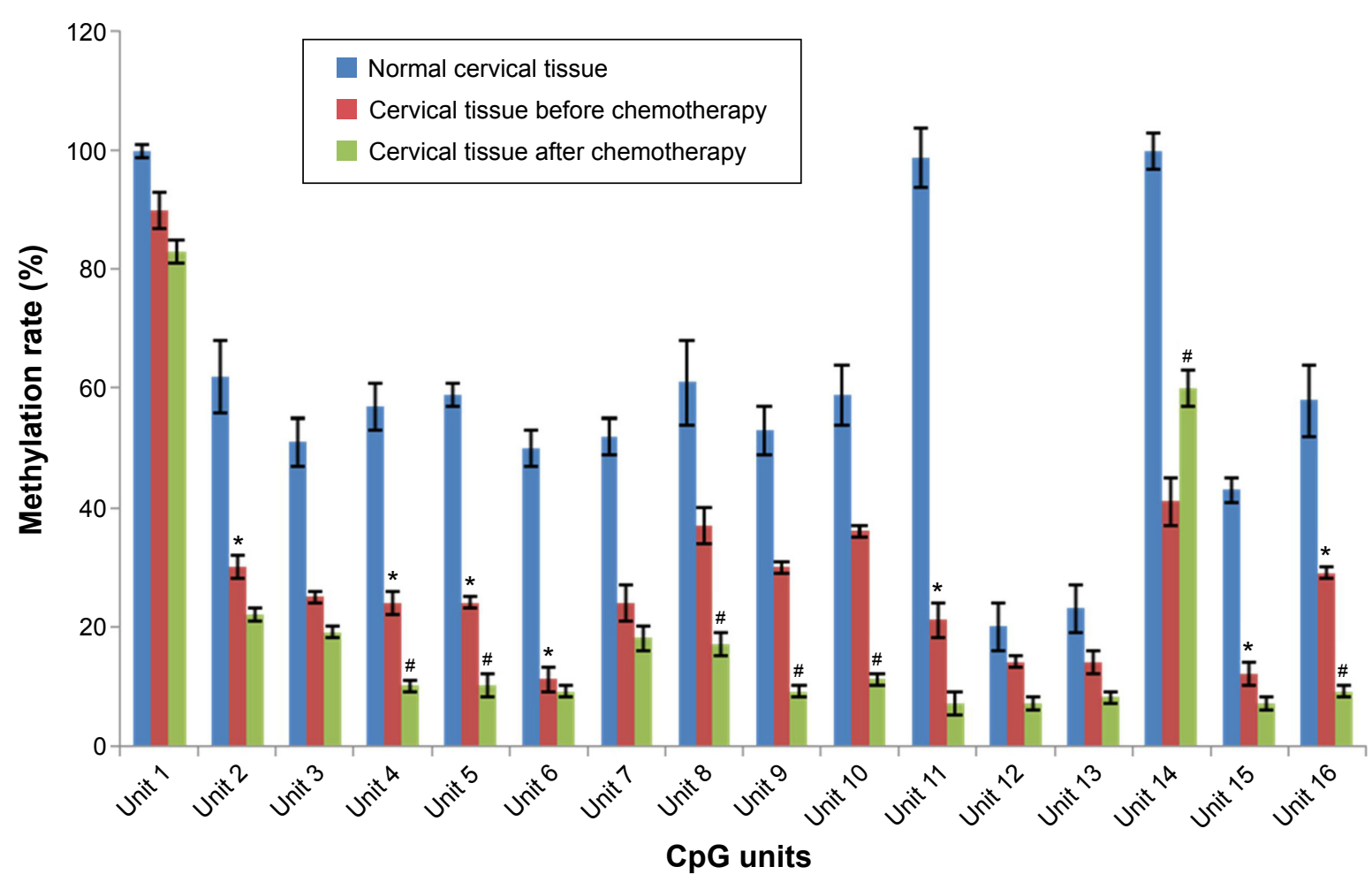

Figure 3 Mean methylation rate of MDRI gene $C_{p}$ G units in normal cervical tissues and cervical cancer tissues before and after chemotherapy.

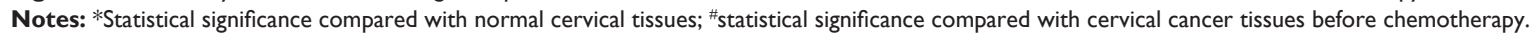

MDR1 hypo-methylation leads to the highest expression of P-gp of tumor cells, consequently reducing the sensibility of tumor cells to chemotherapeutics. ${ }^{16}$ Bebek et al ${ }^{17}$ held that the methylation level of the MDR1 promoter region in head and neck squamous cell carcinoma, which was different from normal mucosal tissue, was closely related to lymphatic metastasis in tumor region.

In the present study, the methylation rate of six $\mathrm{CpG}$ units was higher in cervical cancer tissue before chemotherapy than after chemotherapy, and the methylation rate

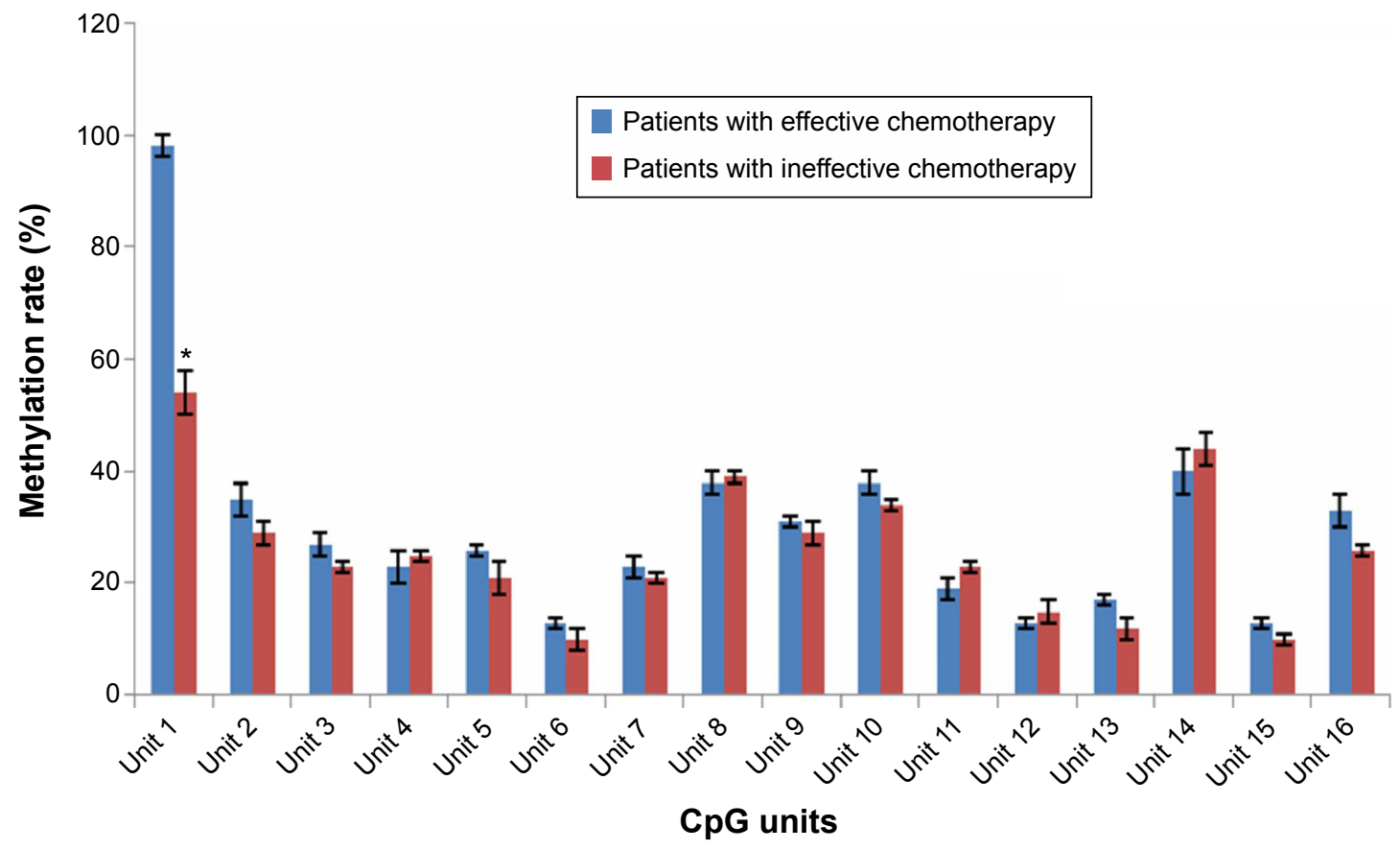

Figure 4 Mean methylation rate of MDRI gene CPG units in patients with different therapeutic effect of chemotherapy. Note: *Statistical significance compared with patients with effective chemotherapy. 
of $\mathrm{CpG} \_2,3$, and 4 loci before chemotherapy in patients with effective chemotherapy was higher than in patients with ineffective chemotherapy, indicating that chemotherapy could change the methylation status of MDRl gene and the chemotherapeutic effect had a certain correlation with the methylation status of $M D R 1$ gene. In addition, the mean methylation rate of $13 \mathrm{CpG}$ units in normal cervical tissue was higher than cervical cancer tissues $(P<0.05)$, revealing the quantitative methylation of MDR $1 \mathrm{CpG}$ units might be a molecular marker of cervical cancer and further providing guidance for identifying cervical cancer.

Although we obtained some of the interesting results, there were also some limitations. First, whether the methylation status of those $\mathrm{CpG}$ loci of MDR1 gene is able to identify the malignant degree also needs to be further studied. Second, whether the $\mathrm{CpG}$ loci of MDR1 could be used for the clinical diagnosis of tumors still needs to be further explored.

\section{Conclusion}

This study proves that the methylation status of the partial MDR1 gene has certain correlation with the chemotherapeutic efficacy of interventional embolism chemotherapy for cervical cancer before operation, at the same time, it can predict the drug sensitivity of tumor to some extent, and provide the theoretical basis for individualized treatment for cervical cancer.

\section{Disclosure}

The authors report no conflicts of interest in this work.

\section{References}

1. Robati M, Holtz D, Dunton CJ. A review of topotecan in combination chemotherapy for advanced cervical cancer. Ther Clin Risk Manag. 2008; 4:213-218.

2. Li PL, Tan HZ. Expression of PPAR $\gamma$, p27 and Ki67 in cervical cancer and its clinical significance. $J$ Int Transl Med. 2015;3:11-17.
3. Benedetti Panici P, Palaia I, Marchetti C, et al. Dose-dense neoadjuvant chemotherapy plus radical surgery in locally advanced cervical cancer: a phase II study. Oncology. 2015;89:103-110.

4. Robova H, Rob L, Halaska MJ, Pluta M, Skapa P. Review of neoadjuvant chemotherapy and trachelectomy: which cervical cancer patients would be suitable for neoadjuvant chemotherapy followed by fertilitysparing surgery? Curr Oncol Rep. 2015;17:446.

5. Martinelli F, Bogani G, Ditto A, et al. How often parametrial involvement leads to post-operative adjuvant treatment in locally advanced cervical cancer after neoadjuvant chemotherapy and type $\mathrm{C}$ radical hysterectomy? Eur J Surg Oncol. 2015;41:1089-1096.

6. Lee JP, Hahn HS, Hwang SJ, et al. Selective cyclooxygenase inhibitors increase paclitaxel sensitivity in taxane-resistant ovarian cancer by suppressing P-glycoprotein expression. J Gynecol Oncol. 2013;24: 273-279.

7. Leibert E, Danckers M, Rom WN. New drugs to treat multidrug-resistant tuberculosis: the case for bedaquiline. Ther Clin Risk Manag. 2014; 10:597-602.

8. Xie J, Li DW, Chen XW, Wang F, Dong P. Expression and significance of hypoxia-inducible factor-1 alpha and MDR1/P-glycoprotein in laryngeal carcinoma tissue and hypoxic Hep-2 cells. Oncol Lett. 2013; 6:232-238.

9. Abbasi M, Lavasanifar A, Uludag H. Recent attempts at RNAi-mediated P-glycoprotein downregulation for reversal of multidrug resistance in cancer. Med Res Rev. 2013;33:33-53.

10. Davis PJ, Incerpi S, Lin HY, Sudha T, Mousa SA. Thyroid hormone and P-glycoprotein in tumor cells. Biomed Res Int. 2015;2015:168427.

11. Gao F, Ye Q, Wan Q, Liu S, Zhou J. Distribution and resistance of pathogens in liver transplant recipients with Acinetobacter baumannii infection. Ther Clin Risk Manag. 2015;11:5051-5055.

12. Vishnukumar S, Umamaheswaran G, Anichavezhi D, et al. P-glycoprotein expression as a predictor of response to neoadjuvant chemotherapy in breast cancer. Indian J Cancer. 2013;50:195-199.

13. Scheiner MA, da Cunha Vasconcelos F, da Matta RR, Dal Bello Figueira R, Maia RC. ABCB1 genetic variation and P-glycoprotein expression/activity in a cohort of Brazilian acute myeloid leukemia patients. J Cancer Res Clin Oncol. 2012;138:959-969.

14. Zhu Z, Wang B, Bi J, et al. Cytoplasmic HuR expression correlates with P-gp, HER-2 positivity, and poor outcome in breast cancer. Tumour Biol. 2013;34:2299-2308.

15. Meng H, Cao Y, Qin J, et al. DNA methylation, its mediators and genome integrity. Int J Biol Sci. 2015;11:604-617.

16. Henrique R, Oliveira AI, Costa VL, et al. Epigenetic regulation of MDR1 gene through post-translational histone modifications in prostate cancer. BMC Genomics. 2013;14:898.

17. Bebek G, Bennett KL, Funchain P, et al. Microbiomic subprofiles and MDR1 promoter methylation in head and neck squamous cell carcinoma. Hum Mol Genet. 2012;21:1557-1565.
Therapeutics and Clinical Risk Management

\section{Publish your work in this journal}

Therapeutics and Clinical Risk Management is an international, peerreviewed journal of clinical therapeutics and risk management, focusing on concise rapid reporting of clinical studies in all therapeutic areas, outcomes, safety, and programs for the effective, safe, and sustained use of medicines. This journal is indexed on PubMed Central, CAS,

\section{Dovepress}

EMBase, Scopus and the Elsevier Bibliographic databases. The manuscript management system is completely online and includes a very quick and fair peer-review system, which is all easy to use. Visit http://www.dovepress.com/testimonials.php to read real quotes from published authors. 